Review

\title{
Expression of Staphylococcal Enterotoxins under Stress Encountered during Food Production and Preservation
}

\author{
Jenny Schelin ${ }^{1}$ (D), Yusak Budi Susilo ${ }^{1}$ and Sophia Johler ${ }^{2, *}$ \\ 1 Applied Microbiology, Department of Chemistry, Lund University, SE-221 00 Lund, Sweden; \\ jenny.schelin@tmb.lth.se (J.S.); yusak.budi_susilo@tmb.lth.se (Y.B.S.) \\ 2 Institute for Food Safety and Hygiene, Vetsuisse Faculty University of Zurich, Winterthurerstrasse 272, \\ 8057 Zurich, Switzerland \\ * Correspondence: sophia.johler@uzh.ch; Tel.: +41-44-6358-680; Fax: +41-44-6358-908
}

Academic Editor: Scott A. Waldman

Received: 19 November 2017; Accepted: 14 December 2017; Published: 15 December 2017

\begin{abstract}
Staphylococcal food poisoning (SFP) is the most prevalent cause of food-borne intoxications worldwide. Consumption of enterotoxins preformed in food causes violent vomiting and can be fatal in children and the elderly. While being repressed by competing bacteria in most matrices, Staphylococcus aureus benefits from crucial competitive advantages in foods with high osmolarity or low $\mathrm{pH}$. During recent years, the long-standing belief in the feasibility of assessing SFP risk based on colony-forming units of $S$. aureus present in food products has been disproven. Instead, researchers and food business operators are acutely aware of the imminent threat arising from unforeseeable enterotoxin production under stress conditions. This paradigm shift led to a variety of new publications enabling an improved understanding of enterotoxin expression under stress conditions encountered in food. The wealth of data provided by these studies is extremely diverse, as it is based on different methodological approaches, staphylococcal strains, stressors, and enterotoxins. Therefore, in this review, we aggregated and critically evaluated the complex findings of these studies, to provide readers with a current overview of the state of research in the field.
\end{abstract}

Keywords: staphylococcal food poisoning; enterotoxin; Staphylococcus aureus; strain specific variation; regulatory circuits

\section{Introduction}

Staphylococcal enterotoxins (SEs) preformed by S. aureus during growth in food are a common cause of staphylococcal food poisoning (SFP). The European Food Safety Authority registered 434 reported SFP outbreaks in 2015, which equals more than half of all food-borne outbreaks associated with bacterial toxins [1]. In the US, the Centers for Disease Control estimate that 240,000 cases of SFP occur each year, leading to 1000 hospitalizations and six fatalities [2]. Shortly after oral intake of SEs, patients may suffer from nausea and violent vomiting, which is often accompanied by watery diarrhea, prostration, and moderate fever. Symptoms usually subside within $24 \mathrm{~h}$, but may be fatal in children and the elderly with a fatality rate of $4.4 \%$ [3].

As the heat-stable SEs are preformed during growth of $S$. aureus in food and cannot be reliably inactivated through food processing [4], prevention of S. aureus growth and toxin formation in food is key to minimizing the risk of intoxication. However, assessing the SFP risk associated with a food product solely based on colony-forming units of $S$. aureus present has recently been shown to be unreliable $[5,6]$. While growth of the organism is repressed by competing bacteria in many food matrices, $S$. aureus exhibits a competitive growth advantage in foods with high sugar or salt 
concentrations or low $\mathrm{pH}$. Understanding the effect of these stressors on enterotoxin expression is crucial to improving risk assessment and to adapting food production parameters to minimize the intoxication risk for the consumer. Within the last few years, a wide variety of different studies have tried to extend the very limited data available on the effect of food-related stressors on SE expression. In this review, we aim to subsume and critically discuss this wealth of novel findings in order to provide readers with a concise and current overview presenting the most striking insights.

\section{Methodological Challenges in Quantifying SE Expression under Stress Conditions}

Various approaches have been used to quantify SE expression under food-related stress conditions either on a transcriptional or translational level. In the past, the formation of SEs under stress conditions has mainly been assessed using immunological methods [7-10]. However, loss of serological recognition does not necessarily equal loss of emetic/biological activity [11].

Lately, there have been advancements in the development of non-immunologically based methods that provide promising ways of detection and quantification that will circumvent the dependency on serological recognition. Methods such as high-performance liquid chromatography (HPLC), reverse phase liquid chromatography coupled with ESI mass spectrometry (LC-ESI/MS), ultra-high-performance liquid chromatography-tandem mass spectrometry (UPLC-MS/MS) and liquid chromatography-mass spectrometry based on multiple reaction monitoring (LC-MS/MS (MRM)) have been developed and evaluated for detection of enterotoxins in different food matrices [12-15]. Although further optimization in the areas of, e.g., sample preparation and detection limits is still needed, these methods are a highly interesting and a promising complementation to existing techniques. By basing measurements on the intrinsic properties of the enterotoxin protein, these tools are independent of sometimes-unreliable antigen-antibody interactions. Thus, many problems associated with conventional immunological SE detection can be solved, including false positive/false negative reactions due to cross-reaction between serotypes, serological modifications of the enterotoxin, or simply breakdown of the antibodies.

Quantitative real-time PCR techniques determining enterotoxin mRNA levels open up a new range of possibilities to study enterotoxin gene expression under stress, and have been suggested to represent a useful tool in assessing the risk of SFP [16]. However, normalization using a sufficient number of reference genes validated under the specific stress conditions applied is of crucial importance. It is necessary to correct for variation introduced by differences in mRNA concentrations among samples, yield of RNA extraction/reverse transcription, as well as amplification efficiency [17]. Validated reference genes for normalization of qPCR assays involving $\mathrm{NaCl}$, lactic acid, glucose and nitrite stress levels frequently encountered in food have been published [18-20].

Recent findings underline the necessity of confirming SE expression data generated using planktonic pure cultures by data obtained through measuring SE formation directly in the food matrix $[5,21]$. However, high-quality antibodies are not readily available for all SEs, and commercial detection kits are currently limited to the classical enterotoxins SEA-SEE, omitting the newly described SEs that are increasingly being associated with SFP outbreaks [22-24]. Immunological detection approaches in the food matrix, and particularly in cheese, may further suffer from low specificity and sensitivity, and false-positive test results have been reported due to matrix components or unspecific IgG binding, necessitating purification and concentration by affinity chromatography and dialysis [25].

Other important factors to consider when estimating or monitoring enterotoxin production in food is the actual virulence capacity of different $S$. aureus strains and whether there is a correlation between growth and toxin production in complex environments. Currently, the microbial safety guidelines of food products are determined by the acceptable concentration of viable cells (CFU per $g$ or $\mathrm{mL}$ ) present in a defined amount of food sample [26,27]. This is partly based on earlier studies demonstrating that a critical population size of $10^{5} \mathrm{CFU} / \mathrm{g}$ or $\mathrm{mL}$ is required for the presence of detectable amounts of enterotoxins [28]. Previous and later work have, however, demonstrated that prediction of enterotoxin concentrations produced in situ based on the number of viable cells is an unreliable indicator for 
predicting enterotoxin levels $[6,20,23,29,30]$. The study by Zeaki et al. [6] showed that even though all three natural isolates used in the study exhibited very similar growth patterns and rates over 14 days of incubation on pork sausages with or without lactic acid treatment, the levels of SEA produced, as well as the enterotoxin production rates, differed significantly. No apparent linkage between absolute cell number or growth rate and enterotoxin production/levels was detected, suggesting that assessment of the intoxication risk associated with a food item based solely on the level of S. aureus CFU detected is unreliable. A study on SFP outbreaks in the UK between 1969 and 1990 found different amounts of viable S. aureus cells, varying from not detectable to $1.5 \times 10^{10} \mathrm{CFU} / \mathrm{g}$, in the investigated food samples [31], a finding consistent with outbreak investigations elsewhere [23]. Combined, the aforementioned challenges emphasize the need for additional, more sensitive and robust tools for SE detection and quantification.

\section{Effect of Food-Related Stressors on the Expression of SEA-SED}

\subsection{SEA}

The effect of stress on sea prophage induction and SEA expression may vary, dependent on the $\mathrm{pH}$, as well as the allelic sea variant and prophage present in the S. aureus strain tested $[32,33]$. Mild $\mathrm{NaCl}$ stress (2\%) was reported to lead to phage induction and increased levels of sea gene produced in the food isolate Sa17, while at the same time resulting in lower SEA levels compared to BHI control conditions [34]. Mild acetic acid stress ( $\mathrm{pH}$ 7-5.5) led to prophage induction and increased sea expression in Mu50 and food isolate Sa45, while no or very low levels of sea mRNA and SEA were detected at pH 5.0-4.5 [32]. Another study observed no effect of sorbic acid stress $(0.15 \%, \mathrm{pH} 5)$ on phage induction, as well as decreased SEA levels using S. aureus Sa17 [34]. Undissociated lactic acid (1.6 mM compared to $0.2 \mathrm{mM}$ ) was reported to be able to increase SEA production of strain cocktails grown in BHI broth [35]. However, treatment of pork sausage with 1-2\% lactic acid was shown to be able to reduce SEA formation [6]. The effect of temperature on SEA production was reported to be strain dependent [36,37]. SEA production was detected at a temperature range of $10{ }^{\circ} \mathrm{C}$ to $45^{\circ} \mathrm{C}[36,37]$, with SEA production rates increasing in most strains with increasing temperatures [37].

Co-culturing of Lactococcus lactis and S. aureus strain MW2 resulted in a slight improvement in maintaining sea expression in the stationary growth phase, whereas expression of other enterotoxin genes was impaired (sec, sel) or unaffected (sek, seg, seh) [38].

Several studies also provide data on SEA expression in meat products. Wallin-Carlquist et al. [5] determined SEA expression in boiled and smoked ham, Serrano ham, and black pepper salami over seven days. The meat product slices were each inoculated with $10^{7} \mathrm{CFU}$ of $S$. aureus outbreak strain SA45. SEA levels detected in boiled and smoked ham after 1 day and in Serrano ham after 7 days of incubation were sufficient to cause SFP, with higher sea mRNA and SEA protein levels observed in boiled ham in comparison to smoked ham. No sea mRNA or SEA was detected in salami [5].

\section{2. $S E B$}

SEB expression is highest during the transition from exponential to stationary growth phase [39-41], coinciding with a peak in the activity of the quorum sensing system Agr (accessory gene regulator) [42,43]. It has been reported that SEB production is not affected by nitrite levels of up to $200 \mathrm{mg} / \mathrm{L}$ [8].

A recent study by Sihto et al. investigated the effect of $\mathrm{NaCl}(4.5 \%)$, nitrite $(150 \mathrm{mg} / \mathrm{L})$, glucose $(30 \%)$, and lactic acid ( $\mathrm{pH} 6.0)$ stress on seb promoter activity for transcriptional fusions of different seb upstream regions of clinical isolates in a USA300 and HG003 strain background [44]. The results of this study showed that mild stress conditions mimicking those encountered during food production and preservation can lead to significant changes in seb promoter activity, with glucose and $\mathrm{NaCl}$ stress reducing seb promoter activity, while lactic acid increased seb promoter activity. Interestingly, a significant effect of the strain background on seb promoter activation was shown, which 
by far surpassed the effect of different stressors on seb promoter activation. The activity of the same seb promoter in HG003 was far lower compared to USA300. However, deletion of sigB in HG003 led to an extreme increase in the activity of the seb promoter, suggesting that repression of the seb promoter in this strain is due to $\operatorname{SigB}$ activity [44].

\subsection{SEC}

There is only very limited data on the effect of food-related stressors on sec expression and, in particular, no data taking into consideration the different SEC variants. Even et al. demonstrated that sec expression is affected in mixed cultures with Lactococcus lactis held at a constant $\mathrm{pH}$ of 6.6 [38]. These conditions had almost no effect on $S$. aureus growth, but strongly affected expression of sec, as well as regulators agr and sarA in MW2. The expression of sec was also reported to be affected by glucose and $\mathrm{NaCl}$ stress $[45,46]$. Levels of sec mRNA and SEC protein were shown to be reduced 16-fold in conditions of $1.2 \mathrm{M} \mathrm{NaCl}$ compared to $0 \mathrm{M} \mathrm{NaCl}$, independently of an intact agr [46].

\subsection{SED}

Recently, sed expression was studied in clinical isolates (RKI1, RKI2, SAI48, BW10, KLT8) under various stress conditions encountered during food production and preservation, including $\mathrm{NaCl}$, sodium nitrite, lactic acid, and glucose stress (30\%). Studies by Sihto et al. showed that $\mathrm{NaCl}$ $(4.5 \%)$ and glucose stress can decrease sed expression, while lactic acid stress had no significant effect on sed expression $[18,47]$. Sihto et al. also reported that nitrite stress $(150 \mathrm{mg} / \mathrm{L}) \mathrm{can}$ lead to significantly induced sed mRNA levels, but does not result in higher SED protein levels [20]. First studies also conducted experiments quantifying sed transcription and SED protein formation in the food matrix [30,48]. Márta et al. [30] showed that sed is expressed in various ham products over an extended amount of time, with an increase in sed expression after five days. Susilo et al. [48] measured sed transcription and SED formation on boiled ham for 14 days at $22{ }^{\circ} \mathrm{C}$ in a wild-type strain (RKI1) and isogenic agr mutant, showing that loss of Agr only partially affects SED formation, even in a real food environment [48].

Interestingly, several studies measuring sed expression on both the transcriptional and translational level found that relative sed expression levels did not mirror the SED protein levels detected $[20,48]$. This may be due to regulation at the translational level. Alternatively, it could also reflect accumulation of solutes such as proline and glycine betaine under conditions of osmotic stress in order to maintain hydrostatic pressure, which has been hypothesized to result in impaired secretion of exotoxins [49]. Across studies, authors observed strain-specific variation in response to the different stressors and in the control of sed expression by regulatory elements.

\section{Regulation of SE Expression and Possible Over-Estimation of the Influence of Agr}

The expression of SEA to SEE is regulated by a range of different mechanisms that to a varying extent are also interlinked with each other. Overall, two different groups can be distinguished: the prophage-encoded enterotoxins (SEA and SEE) and the agr-regulated enterotoxins (SEB, SEC, and SED). SEA expression and formation have been demonstrated to be quorum-sensing-independent, and regulation is instead linked to the life cycle of different sea-bearing prophages [33,34,50]. SEE is, in contrast, located on a defective prophage, and no impact of bacterial growth on see expression was found [41,51]. For SEB, SEC, and SED, it has been well established that expression is directly or indirectly positively regulated by the global regulator $a g r$, as well as other global regulatory systems [41,45,52-55]. Agr is a well-characterized two-component quorum-sensing system in S. aureus [54,56-58]. The agr operon encodes three transcripts, RNAI, RNAII, and RNAIII [59]. RNAII encodes for proteins that constitute the quorum-sensing part of the system (AgrA, B, C, and D). This provides signals for the transcription of RNAIII, depending on the density of the bacterial population. RNAIII functions as a regulatory signal and activity indicator of the Agr system, and contains the $\delta$-hemolysin (hld) gene $[59,60]$. Both RNAII and RNAII I transcripts are weakly 
transcribed in the early exponential phase of growth followed by increased expression in the early stationary phase $[59,61,62]$. Consequently, when RNAIII levels are low, S. aureus cells produce more cell-wall associated proteins such as protein A, coagulase and fibronectin-binding protein at the beginning of growth in order to establish attachment to the substrate or host cells. Later, in the early stationary phase, the RNAIII transcript level increases in response to higher cell densities. This leads to a decrease in the transcription of cell-surface proteins and an increase in the transcription of exotoxin proteins such as $\alpha$-toxin, $\beta$ - and $\delta$-hemolysin, TSST- 1 , and enterotoxins $[43,57,59,60,63]$. For SEB and SED, the Agr-mediated effect is indirect, with RNAIII increasing the transcription by repression of the repressor of toxins (Rot), an RNAIII-binding protein that is a member of the S. aureus Sar-family of transcriptional factors [64]. The effect of $a g r$ on SED has been rather well studied, and even though an indirect impact on expression levels has been described, several studies have also shown that the role of agr might have been overestimated [53,65].

It has been reported that loss of the Agr system causes 82\% (5-fold) reduction in SED formation in an in vitro study comparing $a g r^{-}$and $a g r^{+}$derivatives (ISP546 and RN4220) of the SigB-deficient S. aureus NCTC8325 strain [53]. Tseng and co-workers later identified specific sed promoter elements important in Agr control [65]. They reported a 1.7-fold decrease of sed promoter activity in an Agr deficient mutant $\left(\mathrm{Agr}^{-} \mathrm{Rot}^{+}\right)$compared to its isogenic parental strain (Agr+ Rot+), and were able to show that regulation of sed gene transcription was mediated through control of Rot activity by Agr. However, already at this stage, the importance of the Agr system on enterotoxin expression is suspected to be overestimated due to the use of the laboratory strain S. aureus NCTC8325. This strain has a defect in the $\operatorname{sig} B$ operon that affects Agr, Rot, and Sar global regulators, and has been reported to increase the expression of RNAIII [66-69]. The effect of loss of Agr on SED expression was recently further studied using clinical S. aureus isolates [20,47], and growth in both defined laboratory medium and a food matrix. Growth in Luria Bertani (LB) broth with or without salt stress revealed no significant differences in SED concentration in three $S$. aureus agr deletion mutants compared to isogenic wild types. Interestingly, for SEB, loss of agr was found to significantly decrease promoter activity in another study performed in LB, using strains with intact $\operatorname{sig} B$ operon, underlining the importance of considering both strain- and enterotoxin-specific variation in S. aureus [44].

Studies investigating the influence of agr on SE expression have so far almost exclusively relied on planktonic growth in cultivation broth, which only partially reflects conditions encountered in the food matrix. A recent study investigated, for the first time, the effect of agr on sed transcript levels in a S. aureus food isolate directly in the food matrix [48]. The study showed that sed transcript levels of an agr mutant were similar to its isogenic wild type when grown on boiled ham. This strongly supports previous findings suggesting that regulation of SED is not as strongly dependent on the Agr system as previously believed, and that high concentrations of SED may be produced independently of $a g r$ [54].

\section{Conclusions}

Taken together, the above compiled findings regarding the effect of different food-related stressors underline the importance of further studies directly in the food matrix. Rather than laboratory strains, strains isolated from food samples and clinical cases of SFP should be used in order to account for the influence of a complex growth milieu combined with the pronounced strain-specific variation observed in S. aureus. Additional studies on the impact of regulatory elements will also be crucial in understanding the complex, intertwined regulatory networks controlling SE expression. Through an ongoing expansion of data concerning $S$. aureus growth behavior and SE production, we can improve risk assessment and consumer safety by supporting food business operators in the adaptation of food production processes and formulations in order to maximize food safety. Due to the complex effects of stressors on the production of various enterotoxins, these adaptations need to be tailored to and evaluated for each specific production process.

Author Contributions: S.J. devised the conceptual design. S.J., J.S., and Y.B.S. wrote, critically revised and approved the final version of the manuscript. 
Conflicts of Interest: The authors declare no conflict of interest.

\section{References}

1. EFSA. The Euroean Union summary report on trends and sources of zoonoses, zoonotic agents and food-borne outbreaks in 2015. EFSA J. 2016, 14. [CrossRef]

2. Scallan, E.; Hoekstra, R.M.; Angulo, F.J.; Tauxe, R.V.; Widdowson, M.-A.; Roy, S.L.; Jones, J.L.; Griffin, P.M. Foodborne illness acquired in the United States-Major pathogens. Emerg. Infect. Dis. 2011, 17, 7-15. [CrossRef] [PubMed]

3. Doyle, M.P.; Beuchat, L.R. Food Microbiology: Fundamentals and Frontiers, 3rd ed.; ASM Press: Washington, DC, USA, 2007.

4. Le Loir, Y.; Baron, F.; Gautier, M. Staphylococcus aureus and food poisoning. Genet. Mol. Res. 2003, 2, 63-76. [PubMed]

5. Wallin-Carlquist, N.; Márta, D.; Borch, E.; Rådström, P. Prolonged expression and production of Staphylococcus aureus enterotoxin A in processed pork meat. Int. J. Food Microbiol. 2010, 141, 69-74. [CrossRef] [PubMed]

6. Zeaki, N.; Cao, R.; Skandamis, P.N.; Rådström, P.; Schelin, J. Assessment of high and low enterotoxin A producing Staphylococcus aureus strains on pork sausage. Int. J. Food Microbiol. 2014, 182-183, 44-50. [CrossRef] [PubMed]

7. Genigeorgis, C.; Sadler, W.W. Effect of sodium chloride and $\mathrm{pH}$ on enterotoxin B production. J. Bacteriol. 1966, 92, 1383-1387. [PubMed]

8. McLean, R.A.; Lilly, H.D.; Alford, J.A. Effects of meat-curing salts and temperature on production of staphylococcal enterotoxin B. J. Bacteriol. 1968, 95, 1207-1211. [PubMed]

9. Troller, J.A. Effect of water activity on enterotoxin B production and growth of Staphylococcus aureus. Appl. Microbiol. 1971, 21, 435-439. [PubMed]

10. Domenech, A.; Hernandez, F.J.; Orden, J.A.; Goyache, J.; Lopez, B.; Suarez, G.; Gomez-Lucia, E. Effect of six organic acids on staphylococcal growth and enterotoxin production. Z. Lebensm. Unters. Forsch. 1992, 194, 124-128. [CrossRef] [PubMed]

11. Bennett, R.W. Staphylococcal enterotoxin and its rapid identification in foods by enzyme-linked immunosorbent assay-based methodology. J. Food Prot. 2005, 68, 1264-1270. [CrossRef] [PubMed]

12. Williams, R.R.; Wehr, C.T.; Rogers, T.J.; Bennett, R.W. High-performance liquid chromatography of staphylococcal enterotoxin B. J. Chromatogr. 1983, 266, 179-186. [CrossRef]

13. Sospedra, I.; Soler, C.; Mañes, J.; Soriano, J.M. Rapid whole protein quantitation of staphylococcal enterotoxins A and B by liquid chromatography/mass spectrometry. J. Chromatogr. A 2012, 1238, 54-59. [CrossRef] [PubMed]

14. Muratovic, A.; Hagström, T.; Rosén, J.; Granelli, K.; Hellenäs, K.-E. Quantitative analysis of staphylococcal enterotoxins $\mathrm{A}$ and $\mathrm{B}$ in food matrices using ultra high-performance liquid chromatography tandem mass spectrometry (UPLC-MS/MS). Toxins (Basel) 2015, 7, 3637-3656. [CrossRef] [PubMed]

15. Andjelkovic, M.; Tsilia, V.; Rajkovic, A.; de Cremer, K.; van Loco, J. Application of LC-MS/MS MRM to determine staphylococcal enterotoxins (SEB and SEA) in milk. Toxins (Basel) 2016, 8, 118. [CrossRef] [PubMed]

16. Lee, Y.-D.; Moon, B.-Y.; Park, J.-H.; Chang, H.-I.; Kim, W.J. Expression of enterotoxin genes in Staphylococcus aureus isolates based on mRNA analysis. J. Microbiol. Biotechnol. 2007, 17, 461-467. [PubMed]

17. Bustin, S.A.; Benes, V.; Garson, J.A.; Hellemans, J.; Huggett, J.; Kubista, M.; Mueller, R.; Nolan, T.; Pfaffl, M.W.; Shipley, G.L. The MIQE guidelines: Minimum information for publication of quantitative real-time PCR experiments. Clin. Chem. 2009, 55, 611-622. [CrossRef] [PubMed]

18. Sihto, H.M.; Tasara, T.; Stephan, R.; Johler, S. Growth behavior and temporal enterotoxin D expression of Staphylococcus aureus strains under glucose and lactic acid stress. Food Control 2016, 62, 69-73. [CrossRef]

19. Sihto, H.-M.; Tasara, T.; Stephan, R.; Johler, S. Validation of reference genes for normalization of qPCR mRNA expression levels in Staphylococcus aureus exposed to osmotic and lactic acid stress conditions encountered during food production and preservation. FEMS Microbiol. Lett. 2014, 356, 134-140. [CrossRef] [PubMed] 
20. Sihto, H.-M.; Budi Susilo, Y.; Tasara, T.; Rådström, P.; Stephan, R.; Schelin, J.; Johler, S. Effect of sodium nitrite and regulatory mutations $\Delta a g r, \Delta s a r A$, and $\Delta s i g B$ on the mRNA and protein levels of staphylococcal enterotoxin D. Food Control 2016, 65, 37-45. [CrossRef]

21. Schelin, J.; Wallin-Carlquist, N.; Cohn, M.T.; Lindqvist, R.; Barker, G.C.; Rådström, P. The formation of Staphylococcus aureus enterotoxin in food environments and advances in risk assessment. Virulence 2011, 2, 580-592. [CrossRef] [PubMed]

22. Ikeda, T.; Tamate, N.; Yamaguchi, K.; Makino, S. Mass outbreak of food poisoning disease caused by small amounts of staphylococcal enterotoxins A and H. Appl. Environ. Microbiol. 2005, 71, 2793-2795. [CrossRef] [PubMed]

23. Johler, S.; Giannini, P.; Jermini, M.; Hummerjohann, J.; Baumgartner, A.; Stephan, R. Further evidence for staphylococcal food poisoining outbreaks caused by egc-encoded enterotoxins. Toxins (Basel) 2015, 7, 997-1004. [CrossRef] [PubMed]

24. Pereira, M.L.; Do Carmo, L.S.; Dos Santos, E.J.; Pereira, J.L.; Bergdoll, M.S. Enterotoxin H in staphylococcal food poisoning. J. Food Prot. 1996, 59, 559-561. [CrossRef]

25. Becker, H.; Bürk, C.; Märtlbauer, E. Staphylokokken-Enterotoxine: Bildung, Eigenschaften und Nachweis. J. Verbrauch. Leb. 2007, 2, 171-189. [CrossRef]

26. ECDC. Commission Regulation (EC) No 2073/2005 on Microbiological Criteria for Foodstuffs 2073; ECDC: Solna Municipality, Sweden, 2005.

27. FDA. Foodborne pathogenic microorganism \& natural toxins handbook. In Bad Bug Book; US Food and Drug Administration/The Center of Food Safety and Applied Nutrition (US FDA/CFSAN): Maryland, MD, USA, 2010.

28. Bennett, R.W.; Monday, S.R. Staphylococcus aureus. In International Handbook of Foodborne Pathogens; Miliotis, D.M., Bier, W.J., Eds.; Taylor \& Francis: Abingdon, UK, 2003; pp. 41-59.

29. Lindqvist, R.; Sylén, S.; Vågsholm, I. Quantitative microbial risk assessment exemplified by Staphylococcus aureus in unripened cheese made from raw milk. Int. J. Food Microbiol. 2002, 15, 155-170. [CrossRef]

30. Márta, D.; Wallin-Carlquist, N.; Schelin, J.; Borch, E.; Rådström, P. Extended staphylococcal enterotoxin D expression in ham products. Food Microbiol. 2011, 28, 617-620. [CrossRef] [PubMed]

31. Wieneke, A.A.; Roberts, D.; Gilbert, R.J. Staphylococcal food poisoning in the United Kingdom, 1969-1990. Epidemiol. Infect. 1993, 110, 519-531. [CrossRef] [PubMed]

32. Wallin-Carlquist, N.; Cao, R.; Márta, D.; da Silva, A.S.; Schelin, J.; Rådström, P. Acetic acid increases the phage-encoded enterotoxin A expression in Staphylococcus aureus. BMC Microbiol. 2010, 10, 1-10. [CrossRef] [PubMed]

33. Cao, R.; Zeaki, N.; Wallin-Carlquist, N.; Skandamis, P.N.; Schelin, J.; Rådström, P. Elevated enterotoxin A expression and formation in Staphylococcus aureus and its association with prophage induction. Appl. Environ. Microbiol. 2012, 78, 4942-4948. [CrossRef] [PubMed]

34. Zeaki, N.; Rådström, P.; Schelin, J. Evaluation of Potential Effects of $\mathrm{NaCl}$ and sorbic acid on staphylococcal enterotoxin A formation. Microorganisms 2015, 3, 551-566. [CrossRef] [PubMed]

35. Rosengren, A.; Lindblad, M.; Lindqvist, R. The effect of undissociated lactic acid on Staphylococcus aureus growth and enterotoxin A production. Int. J. Food Microbiol. 2013, 162, 159-166. [CrossRef] [PubMed]

36. Schmitt, M.; Schuler-Schmid, U.; Schmidt-Lorenz, W. Temperature limits of growth, TNase and enterotoxin production of Staphylococcus aureus strains isolated from foods. Int. J. Food Microbiol. 1990, 11, 1-19. [CrossRef]

37. Tsutsuura, S.; Shimamura, Y.; Murata, M. Temperature dependence of the production of staphylococcal enterotoxin A by Staphylococcus aureus. Biosci. Biotechnol. Biochem. 2013, 77, 30-37. [CrossRef] [PubMed]

38. Even, S.; Charlier, C.; Nouaille, S.; Ben Zakour, N.L.; Cretenet, M.; Cousin, F.J.; Gautier, M.; Cocaign-Bousquet, M.; Loubière, P.; Le Loir, Y. Staphylococcus aureus virulence expression is impaired by Lactococcus lactis in mixed cultures. Appl. Environ. Microbiol. 2009, 75, 4459-4472. [CrossRef] [PubMed]

39. Bergdoll, M.S. Staphylococcal intoxications. Foodborne Infect. Intox. 1979, 443-490.

40. Czop, J.K.; Bergdoll, M.S. Staphylococcal enterotoxin synthesis during the exponential, transitional, and stationary growth phases. Infect. Immun. 1974, 9, 229-235. [PubMed]

41. Derzelle, S.; Dilasser, F.; Duquenne, M.; Deperrois, V. Differential temporal expression of the staphylococcal enterotoxins genes during cell growth. Food Microbiol. 2009, 26, 896-904. [CrossRef] [PubMed] 
42. Bischoff, M.; Dunman, P.; Kormanec, J.; Macapagal, D.; Murphy, E.; Mounts, W.; Berger-Bächi, B.; Projan, S. Microarray-based analysis of the Staphylococcus aureus sigmaB regulon. J. Bacteriol. 2004, 186, 4085-4099. [CrossRef] [PubMed]

43. Bronner, S.; Monteil, H.; Prevost, G. Regulation of virulence determinants in Staphylococcus aureus: Complexity and applications. FEMS Microbiol. Rev. 2004, 28, 183-200. [CrossRef] [PubMed]

44. Sihto, H.M.; Stephan, R.; Engl, C.; Chen, J.; Johler, S. Effect of food-related stress conditions and loss of $a g r$ and $\operatorname{sig} B$ on seb promoter activity in S. aureus. Food Microbiol. 2017, 65, 205-212. [CrossRef] [PubMed]

45. Regassa, L.B.; Couch, J.L.; Betley, M.J. Steady-state staphylococcal enterotoxin type C mRNA is affected by a product of the accessory gene regulator (agr) and by glucose. Infect. Immun. 1991, 59, 955-962. [PubMed]

46. Regassa, L.B.; Betley, M.J. High sodium chloride concentrations inhibit staphylococcal enterotoxin C gene (sec) expression at the level of sec mRNA. Infect. Immun. 1993, 61, 1581-1585. [PubMed]

47. Sihto, H.-M.; Tasara, T.; Stephan, R.; Johler, S. Temporal expression of the staphylococcal enterotoxin D gene under $\mathrm{NaCl}$ stress conditions. FEMS Microbiol. Lett. 2015, 362, 1-7. [CrossRef] [PubMed]

48. Susilo, Y.B.; Sihto, H.M.; Rådström, P.; Stephan, R.; Johler, S.; Schelin, J. Reduced enterotoxin D formation on boiled ham in Staphylococcus aureus $\Delta a g r$ mutant. Toxins (Basel) 2017, 9, 263. [CrossRef] [PubMed]

49. Bae, J.H.; Miller, K.J. Identification of two proline transport systems in Staphylococcus aureus and their possible roles in osmoregulation. Appl. Environ. Microbiol. 1992, 58, 471-475. [PubMed]

50. Sumby, P.; Waldor, M.K. Transcription of the toxin genes present within the staphylococcal phage $\varphi S a 3 \mathrm{~ms}$ is intimately linked with the phage's life cycle. J. Bacteriol. 2003, 185, 6841-6851. [CrossRef] [PubMed]

51. Couch, J.L.; Soltis, M.T.; Betley, M.J. Cloning and nucleotide sequence of the type E staphylococcal enterotoxin gene. J. Bacteriol. 1988, 170, 2954-2960. [CrossRef] [PubMed]

52. Gaskill, M.E.; Khan, S.A. Regulation of the enterotoxin B gene in Staphylococcus aureus. J. Biol. Chem. 1988, 263, 6276-6280. [PubMed]

53. Bayles, K.W.; Iandolo, J.J. Genetic and molecular analyses of the gene encoding staphylococcal enterotoxin D. J. Bacteriol. 1989, 171, 4799-4806. [CrossRef] [PubMed]

54. Yarwood, J.M.; Schlievert, P.M. Quorum sensing in Staphylococcus infections. J. Clin. Investig. 2003, 112, 1620-1625. [CrossRef] [PubMed]

55. Otero, A.; Garcia, M.L.; Garcia, M.C.; Moreno, B.; Bergdoll, M.S. Production of staphylococcal enterotoxins C1 and C2 and thermonuclease throughout the growth cycle. Appl. Environ. Microbiol. 1990, 56, 555-559. [PubMed]

56. Novick, R.P. Autoinduction and signal transduction in the regulation of staphylococcal virulence. Mol. Microbiol. 2003, 48, 1429-1449. [CrossRef] [PubMed]

57. Novick, R.P.; Geisinger, E. Quorum sensing in Staphylococci. Annu. Rev. Genet. 2008, 42, 541-564. [CrossRef] [PubMed]

58. Thoendel, M.; Kavanaugh, J.S.; Flack, C.E.; Horswill, A.R. Peptide signaling in the Staphylococci. Chem. Rev. 2011, 111, 117-151. [CrossRef] [PubMed]

59. Novick, R.P.; Ross, H.F.; Projan, S.J.; Kornblum, J.; Kreiswirth, B.; Moghazeh, S. Synthesis of staphylococcal virulence factors is controlled by a regulatory RNA molecule. EMBO J. 1993, 12, 3967-3975. [PubMed]

60. Janzon, L.; Arvidson, S. The role of the delta-lysin gene (hld) in the regulation of virulence genes by the accessory gene regulator (agr) in Staphylococcus aureus. EMBO J. 1990, 9, 1391-1399. [PubMed]

61. Dunman, P.; Murphy, E.; Haney, S. Transcription profiling-based identification of Staphylococcus aureus genes regulated by the agr and/or sarA Loci. J. Bacteriol. 2001, 183, 7341-7353. [CrossRef] [PubMed]

62. Morfeldt, E.; Tegmark, K.; Arvidson, S. Transcriptional control of the agr-dependent virulence gene regulator, RNAIII, in Staphylococcus aureus. Mol. Microbiol. 1996, 21, 1227-1237. [CrossRef] [PubMed]

63. Vandenesch, F.; Kornblum, J.; Novick, R.P. A temporal signal, independent of agr, is required for hla but not spa transcription in Staphylococcus aureus. J. Bacteriol. 1991, 173, 6313-6320. [CrossRef] [PubMed]

64. Said-Salim, B.; Dunman, P.M.; McAleese, F.M.; Macapagal, D.; Murphy, E.; McNamara, P.J.; Arvidson, S.; Foster, T.J.; Projan, S.J.; Kreiswirth, B.N. Global regulation of Staphylococcus aureus genes by Rot. J. Bacteriol. 2003, 185, 610-619. [CrossRef] [PubMed]

65. Tseng, C.W.; Zhang, S.; Stewart, G.C. Accessory gene regulator control of staphyloccoccal enterotoxin D gene expression. J. Bacteriol. 2004, 186, 1793-1801. [CrossRef] [PubMed] 
66. Schmidt, K.A.; Donegan, N.P.; Kwan, W.A., Jr.; Cheung, A. Influences of sigmaB and agr on expression of staphylococcal enterotoxin B (seb) in Staphylococcus aureus. Can. J. Microbiol. 2004, 50, 351-360. [CrossRef] [PubMed]

67. Horsburgh, M.J.; Aish, J.L.; White, I.J.; Shaw, L.; Lithgow, J.K.; Foster, S.J. $\sigma B$ modulates virulence determinant expression and stress resistance: Characterization of a functional $r s b U$ strain derived from Staphylococcus aureus 8325-4. J. Bacteriol. 2002, 184, 5457-5467. [CrossRef] [PubMed]

68. Cassat, J.; Dunman, P.M.; Murphy, E.; Projan, S.J.; Beenken, K.E.; Palm, K.J.; Yang, S.-J.; Rice, K.C.; Bayles, K.W.; Smeltzer, M.S. Transcriptional profiling of a Staphylococcus aureus clinical isolate and its isogenic agr and sarA mutants reveals global differences in comparison to the laboratory strain RN6390. Microbiology 2006, 152, 3075-3090. [CrossRef] [PubMed]

69. Lauderdale, K.J.; Boles, B.R.; Cheung, A.L.; Horswill, A.R. Interconnections between SigmaB, agr, and Proteolytic Activity in Staphylococcus aureus biofilm maturation. Infect. Immun. 2009, 77, 1623-1635. [CrossRef] [PubMed]

(C) 2017 by the authors. Licensee MDPI, Basel, Switzerland. This article is an open access article distributed under the terms and conditions of the Creative Commons Attribution (CC BY) license (http://creativecommons.org/licenses/by/4.0/). 